\title{
Developing a scale to measure tourist perceived safety
}

\begin{abstract}
Safety for tourists at places visited is essential to their enjoyment and experiences, as well as a determinant of destination success. Yet, little attention has been paid to the conceptualization and scale development for tourist perceived safety at destinations (TPSD). The primary purpose of this research was to identify the dimensions of TPSD and develop a scale for measuring it based on safety system theory. A three-stage study in a mixed-method design was conducted to develop and validate TPSD. Stage 1 identified the dimensions and initial items of TPSD through extensive literature reviewing and content analysis of travel blogs. In stage $2(n=300)$, an explanatory factor analysis was conducted to refine and validate the preliminary items. Stage $3(n=1,830)$ provided empirical support for a 20-item, five-dimension (human, facility and equipment, natural environment, social environment, management) TPSD scale through confirmatory factor analysis.
\end{abstract}

\section{Keywords}

Perceived safety, safety system theory, man-machine-media-management (4M), scale development

\section{Introduction}

Safety is a basic need of tourists. People are highly sensitive to safety and security issues in tourism decision-making, and even minor crises in one part of the world may trigger strong tourism demand reactions in other areas through the "effect of generalization" 
(Seabra, Dolnicar, Abrantes, and Kastenholz, 2013). Peace, safety and security are the critical conditions for the normal development of destinations, and thus are basic determinants of success (Cavlek, 2002; Chauhan, 2007; Amir, Ismail, and See, 2015). Many types of safety risks and crises are present in contemporary tourism, which can have devastating effects on destinations, including the Corona virus pandemic of early 2020. Consequently, strengthening safety management systems and creating conditions for tourists to feel safer are critical to the sustainable development of destinations.

Safety is a stable and orderly condition, and safety concerns and risks are present as parallel concepts (Sönmez and Graefe, 1998). Normally, travel safety is a concept that is the opposite to travel risk. Travel risk is defined as the possibility of experiencing danger while engaging in travel or the consciousness of security and knowledge of the likelihood of harm during travel (Fischhoff, Watson, and Hope, 1984; Park and Reisinger, 2010). Thus, travel safety is defined as the degree of risk that can be tolerated during travel, which is a collective term for tourism activities in a balanced, stable and orderly condition. Generally, travel safety is manifested in the normal condition of tourists without threat, loss, or injury during travel (Chauhan, 2007; George, 2003; 2010), and tourist personal assessments of these conditions constitutes TPSD (Chauhan, 2007). TPSD is a subjective impression and assessment of safety information and aspects based on people's past experiences (Seabra et al., 2013). Crisis events, such as terrorism, crimes, and natural disasters, are recognized as critical determinants of the levels of TPSD (Seabra et al., 2013; George, 2003). However, the incidents and safety information 
available to tourists at destinations vary in sources, types, and nature. Additionally, the information may be influenced by the characteristics of the natural environment (Rittichainuwat, 2013), tour leader service quality (Wang, Jao, Chan, and Chung, 2010), or management actions of government (Kılıçlar, Uşaklı, and Tayfun, 2017). George (2003) argued that tourist perceptions of safety and security may be derived from several sources, such as personal experiences of crime, discussions with friends about crime, and exposure to crime through mass media as well as perceptions of police effectiveness. These different sources and amounts of safety information lead to varying types and levels of TPSD. For example, terrorist attacks and natural disasters are two crises dissimilar in circumstances and causes. Terrorist attacks reduce safety expectations and confidence, and lead to sharp declines in tourism demand (Kapuściński and Richards, 2016; Pizam and Smith, 2000). Natural disasters are more readily understood by tourists because of their unpredictability and lack of human involvement and negative influences on TPSD are more limited (Rittichainuwat, 2013; Okuyama, 2018). Therefore, it is suggested that there are hierarchical levels of tourist safety perceptions and the identification of TPSD dimensions could deliver guidance for destinations to offer safer environments and have effective management practices in crises.

Currently, TPSD is an important construct in tourism research and many scholars have measured it in different situations with diverse scales (Echtner and Ritchie, 1993; George, 2003; 2010; Rittichainuwat and Chakrabort, 2012). The measurement of TPSD could be described in three ways. First, TPSD is measured as a sub-dimension of 
destination image. For example, to measure the components of destination image completely, Echtner and Ritchie (1993) regarded safety perception as a sub-dimension of destination image, reflecting tourist evaluations of image elements of friendliness, comfort, and security. To some extent, safety perception is subordinated to tourist perception of destination safety image, and it is a prerequisite for an ideal destination image (Chauhan, 2007; Chi and Qu, 2008; Chen, 2007). George (2003) also mentioned that if tourists feel unsafe or threatened at destinations, they can develop negative impressions. Second, TPSD is considered to be a one-dimensional measurement structure for assessing tourist safety perceptions in diverse situations (such as touring, shopping, driving). For example, TPSD is measured by asking tourists to express their overall sense of safety on a number of issues, such as walking streets at night, touring cities in the daytime, using public transportation, driving around cities, and staying in accommodations (George, 2003). This is the most widely used measurement approach for TPSD currently (Patwardhan et al., 2020). Baokye (2012) argued that tourist conceptions of safety are informed by tourism product quality and their perceptions of safety are organized around a three-pronged platform of privacy, orderliness, and professionalism. Thus, TPSD is measured as a multi-dimensional construct in a specific context and orientation. For example, Rittichainuwat and Chakrabort (2012) explored the perceived importance of safety and security measures from the perspective of tourists and service providers. A six-factor pattern of detectors, crisis management, airport and hotel checks, emergency kits, warning systems, and disease control instruments were identified 
(Rittichainuwat and Chakraborty, 2002). Lee et al. (2018) investigated air passenger perceptions of pre-flight safety communication in the context of the commercial airline industry, which consisted of three sub-dimensions (regulation and safety equipment, instructions for equipment, and general information) (Chia-Chen, Wang, and Hsu, 2018). Thus, various measurement structures of TPSD have been proposed, such as the non-independent structure (sub-dimension of destination image), independent structure, and multi-dimensional structure, and the resulting measurement scales have helped to assess tourist safety perceptions in specific situations and travel contexts. However, situations and contexts vary greatly, and these scales often need to be revised because of their limited scope. Therefore, it is imperative that the TPSD measurement structure be systematically examined from a general perspective and to develop a solid theoretical base, which will contribute to the stability and universality of TPSD measurement, filling a significant research gap in tourism research.

Tourist safety perceptions have a major impact on the development of destinations. Due to social, cultural, political, and other external risk factors, the safety perceptions of tourists from different countries and in different contexts are diverse (Seabra et al., 2013). For example, China has a large and growing domestic tourism market and the Chinese lead the world in terms of outbound international tourism expenditures ( $\mathrm{Li}, 2016$; UNWTO, 2018, p. 14). China, with a complex geographical environment, has a variety of destinations with diverse tourism resources and complex safety risk elements, which may comprehensively represent tourist safety perceptions in diverse tourism situations. 
Recently inside and outside of China, several serious accidents (e.g., Phuket, Thailand drownings in 2018; DongFang Star cruise capsizing in the Three Gorges in 2015), involving significant Chinese tourist fatalities, as well as the more recent Corona virus pandemic, have aroused greater attention among Chinese tourists to safety issues, and even become a critical factor influencing travel decisions. Given that perceived safety is a key factor for the development of destinations, it is therefore worthwhile to develop a TPSD scale with respect to Chinese tourists.

The primary purpose of this research was to fill a literature gap by developing a reliable and valid scale for measuring TPSD through a mixed-method research design, which would help to define the construct and identify the sources of safety elements. The rest of this work is organized as follows. First, a clear conceptualization of TPSD is provided based on safety system theory and the $4 \mathrm{M}$ analysis framework. Second, a reliable and valid scale for measuring TPSD is proposed and confirmed. Finally, the theoretical contributions and practical implications are discussed.

\section{Theoretical Background}

There are multiple theories that have been advanced for safety, risk, and accidents. Wildavsky and Dake (1990), for example, reviewed five alternative theories of risk perception (knowledge, personality, economic, political, and cultural). One of their key findings was that "perception of danger is selective" and depends on the situation or specific risk that an individual faces. After testing the alternate theories, they concluded that cultural theory was the best in predicting perceived risk and who was likely to be 
afraid and unafraid. Weber and Johnson (2009), in reviewing decisions under uncertainty, cited expected value theory, expected utility theory, risk-return models, and prospect theory. However, Loewenstein et al. (2001) criticized previous theories in being almost exclusively cognitive without giving any attention to feelings and emotions.

Having reviewed the potential theories on which to base this research and giving due consideration to the particular culture that exists in China, the research team decided to use safety system theory. Tourism represents a specific risk situation and as yet does not have its own dedicated theory related to safety.

\section{Safety System Theory}

A system is composed of several elements that interact and depend on each other according to a specific structure and is a unified whole with a specific function. The safety system is composed of safety elements in a specific form and is a system that realizes safety and security functions (Edwards, 1972; Rasmussen and Suedung, 2000;

Leveson, 2004; Li, Zhang, and Liang, 2017). Safety system theory identifies the common patterns of accidents and safety management from the perspective of a system, and its main research concepts include accident and safety systems (Leveson, 2011; Lower, Magott, and Skorupski, 2018). The accident system involves four elements, e.g. dangerous behavior of humans, unsafe condition of facilities, risks in the environment, and insufficient management measures, commonly referred to as the " $4 \mathrm{M}$ " elements (Page, Bentley, and Walker, 2005; Xie, Zhang, Chen, Morrison, and Lin, 2020). The elements of the safety system are comprised of human safety capabilities (e.g., ability, 
knowledge, and psychological safety); safety and reliability of equipment and environments (e.g., intrinsic, design, and use safety); safety functions of energy production processes (e.g., effective control of energy); and safety information flow (e.g., effective management procedures) (Edwards, 1972). Thus, the 4Ms can be used to analyze the four risk factors leading to accidents and the four safety elements to ensure system safety.

TPSD indicates tourist subjective evaluations and assessments of various safety elements and conditions at destinations. In other words, TPSD can be conceptualized as tourist perceptions of the "travel safety system" and it integrates assessments of the risk-induced factors of the accident system and the elements of the safety system. In addition, safety perceptions can be understood as feelings of being "safe" and being protected against risks posed by any undesirable events (Sönmez and Graefe, 1998). Thus, TPSD involves a complex and dynamic cognitive process that occurs with the interaction of these four elements (4Ms). Effects, threats, and any other deviations influence tourist safety expectations and assessments and create negative TPSD. Currently, safety system theory has been widely recognized and applied in the fields of coal mining (Song and Xie, 2014), marine transportation (Chen, 2014), construction projects (Jamot and Park, 2019) and engineering management (Mao and $\mathrm{Xu}, 2011)$. In tourism, Bentley and Page applied the $4 \mathrm{M}$ analysis framework to investigate the nature and extent of New Zealand adventure tourism injury problems, and a range of client, equipment, environmental, and organizational risk factors were identified (Page, Bentley, and Walker, 2005; Bentley, 
Page, Meyer, Chalmers, and Laird, 2001). Thus, it is appropriate to introduce safety system theory into TPSD research and this investigation identified the tourist safety perception structure at destinations based on safety system theory and the $4 \mathrm{M}$ analysis framework.

\section{Tourist Perceived Safety at Destinations (TPSD)}

Tourist perceived safety is based on a comprehensive judgment of the stability of the destination, including the anticipated level of safety for the physical self and personal property. It is the expressible set of positive imagery that promotes normal tourism activities, such as a reliable tourism sector, stable social order, balanced environment, and the friendliness of locals (Chauhan, 2007; George, 2003; 2010; Koo, Collins, Williamson, and Caponecchia, 2019). To some extent, TPSD is the perceived image of the safety of a destination. Thus, TPSD has been identified as an antecedent influencing people's travel decision-making processes, which has a fundamental impact on satisfaction, loyalty, and revisit intentions (Fourie, Rossello-Nadal, and Santana-Gallego, 2020; Patwardhan et al., 2020; Sönmez and Graefe, 1998).

Tourists form safety assessments based on different sources of safety information to which they are exposed (Seabra et al., 2013), such as natural environments, public security systems, interactions between tourists and residents, and facilities and equipment. Also, TPSD is affected by people's evaluations in particular behavioral settings (e.g., adventure travel vs. rural tourism) and specific destination locations (e.g., mountainous 
areas vs. plains). Grounded upon the 4M analysis framework and safety system theory, this research conceptualized TPSD as a multi-dimensional construct consisting of humans, facilities and equipment, environments, and management (4Ms).

\section{Perceived Safety of Human Elements (PSH)}

PSH refers to safety assessments and perceptions of individual behavior in tourism settings. It is an expressible set of positive human dimensions associated with normal tourism activity. This includes the behavior of tour guides, tourism operators, residents, fellow travelers, and tourists themselves. Variations in gender, age, risk tolerance, risk-related competencies, and prior knowledge among individuals may generate differences in the processing of safety information about destinations, thereby affecting TPSD (Sönmez and Graefe, 1998; George, 2010; Williams and Baláž, 2013; Sharifpour, Walters and Ritchie, 2014; Fourie et al., 2020). For example, the phenomenon of misbehavior is common in tour groups. This can result in verbal and physical violence, and frauds, scams and theft that disrupt tour itineraries and damage travel experiences, leading sometimes to injuries or loss of personal property (Tsaur, Cheng, and Hong, 2019). In addition, the features of intangibility, perishability, and inseparability of services exacerbate the safety of tourism activities (Mitchell and Greatorex, 1993; Williams and Baláž, 2013). Service quality and the safety awareness of tourism operators are critical factors promoting actual and perceived safety, which constitute an important component of TPSD as well (Caber and Albayrak, 2016). Additionally, the emotional 
solidarity (positive sentiments one feels for another) with residents underpins the perception of safety. High levels of emotional solidarity (particularly to the dimension of feeling welcome) encourage tourists to perceive destinations as relatively safe (Woosnam, Shafer, and Scott, 2015).

\section{Perceived Safety of Facility and Equipment Elements (PSFE)}

PSFE refers to safety assessments and perceptions of the state of facilities and equipment within destinations. They represent the demonstrable set of positive facility and equipment elements that support normal tourism activity. The facilities and equipment in destinations must be regularly inspected and tested, maintained, and updated. Also, the appropriate matching of facilities and equipment with the specific tourists being served further enhances safety (Bentley et al., 2001).

The stable and secure operation of facilities and equipment is an important safety factor for tourists who are already within destinations. In hotels, people are concerned about safety standards of particular facilities and equipment. For example, fire prevention systems, emergency lighting systems, electronic door-locks, food safety, and safety screening are important factors in hotel selection (Chan and Lam, 2013; Sierra, Rubio-Romero, and Gámez, 2012). People with physical disabilities (PwPD) have elevated safety expectations and perceptions regarding accessibility, assistive devices, and professional equipment, which are significant predictors of their hotel satisfaction (Ozkan, 2017). For adventure travel, high-risk activity such as whitewater rafting, hang-gliding, mountain- and rock-climbing, bungee jumping, and scuba diving are highly 
dependent on the safety performance of equipment and facilities, and those who assist them. Failures in these lead to accidents and readily create negative safety impressions of destinations and operators. Adding risk warning systems serves as a way to more effectively communicate levels of dangers and the appropriate behaviors and enhance safety perceptions of destinations and operators (Rittichainuwat, 2008, 2013). Thus, the safety of facilities and equipment is a tool for promoting activities and constitutes an important information element for TPSD.

Perceived Safety of Environmental Elements (PSE)

PSE refers to safety assessments and perceptions of the environmental elements of destinations. They are the articulable positive environmental elements that underlie normal tourism activity. There are two sub-categories of the natural environment and the social-cultural context. Information about safety concerns in natural environments and in particular societies has a positive impact on TPSD, although their characteristics and sources are different.

The natural environment is composed of physical resources such as water bodies, mountains, vegetation, wildlife, and climate. They provide an attraction base for the development of destinations and carry information for people to assess safety risk levels. For example, destinations with high-quality and popular natural landscapes, such as pristine beaches, stunning scenery, and distinctive fauna and flora (Chen and Tsai, 2007; Hosany, Ekinci and Uysal, 2007) allow tourists to experience feelings of self-satisfaction, comfort, and enjoyment. Areas prone to natural disasters are different, including 
volcanoes and locations of prior natural disasters. People form their own safety assessments of these places by obtaining relevant data and incident information, and this shapes their safety perceptions (Rittichainuwat, 2013). Climate-sensitive places are complex and multifaceted (Scott and Lemieux, 2010) and may exert particular influences on traveler perceptions. Climate change is leading to an increase in extreme weather conditions (e.g., rising ocean levels, acid rain, haze, and heatwaves), which have a negative impact on travel planning and perceptions of comfort and safety (Freitas, 2010; Mansfeld, Freundlish, and Kutiel, 2004; Hübner and Gössling, 2012). Climate change is a limiting factor that poses risks to be managed by tourists and destinations. Additionally, destinations in alpine, polar, or desert regions have higher levels of sightseeing environment risk, where people are more likely to suffer harm and personal injury such as altitude sickness, hypothermia, or becoming lost (Eitzinger and Wiedemann, 2007).

The social-cultural context is an environmental system created by human social activities, including politics, economics, culture, and local communities. Risks at a global level such as political instability (Gartner and Shen, 1992), economic crises (Alegre, Joaquín, Mateo, and Pou, 2013), international terrorism (Pizam and Smith, 2000; Sönmez and Graefe, 1998; Jenkin, 2006), and war (Smith, 1998) shape travel safety perception at a macro level, and eventually increase the psychological burden on tourists in unfamiliar surroundings. People who are already within destinations may be more concerned with such risks and form individualized safety perceptions by obtaining local information about orderliness, conflicts, and consumption safety. For example, walking streets after 
dark is a good indicator for measuring TPSD because it clearly indicates the level of public security in a destination (George, 2003). Ryan (2003) described tourists as “displaced" persons, who sacrifice normal responsibility and are more risk-prone in unfamiliar areas (Eitzinger and Wiedemann, 2007). People may be victims of theft, robbery, misunderstandings, or violation of road rules even leading to traffic accidents. Therefore, they are more concerned about safety information on public security and transportation (Wilks, Watson, and Faulks, 1999; Choocharukul and Sriroongvikrai, 2017). The quality of foodservice and the availability of a range of prices play an important role in destination choices and experiences (Sheldon and Fox, 1988). Food safety and local hygiene standards constitute significant elements of destination selection and safety perceptions (MacLaurin, 2004; Lee, Pennington-Gray, and Kim, 2019). Safety while shopping is another key area for retail experience evaluations (Yuksel, 2004).

In summary, the safety information on natural environments and social-cultural contexts differs in risk characteristics, sources, and consequences, leading to the formation of two types of perceived environmental safety: perceived safety of natural environments (PENE) and perceived safety of social environments (PSSE). In addition, compared with natural disaster crises, unpredictable and man-made events (e.g., terrorist attacks) may have a more harmful influence on safety perceptions and destination loyalty (Utz, Schultz, and Glocka, 2013; Breitsohl and Garrod, 2016). Thus, it is appropriate to measure PENE and PSSE separately.

Perceived Safety of Management Elements (PSM) 
PSM refers to safety assessments and perceptions of tourism safety management policies and actions and related aspects at the organizational or managerial levels. They represent positive management elements that support normal tourism activity. Destinations should implement special management initiatives, including safety system elements (Rittichainuwat, 2013; Becken and Hughey, 2013; Rittichainuwat, 2008) (e.g., security institutions, contingency plans) and safety behavioral elements (safety information, police and emergency rescue services) (Tyagi, Dhar, and Sharma, 2016; Gurtner, 2016; Putra, 2010). People may encounter these management systems at the destination, influencing their safety perceptions of management. For instance, several countries, such as the UK, Australia, and Spain, have created safety regulations to avoid injuries and deaths in diving tourism and at beaches (Coxon, 2006). Safety measures by government, such as warnings, crisis management and disaster recovery plans enhance the safety images of destinations and can restore tourist confidence even after a crisis (Yetta, 2016; Putra, 2010; Rittichainuwat, 2013). Rittichainuwat (2013) argued that the perceptions of inbound tourists of beach safety were dependent on the availability of a crisis management plan and tsunami evacuation system (Rittichainuwat, 2013). Additionally, several popular destinations (e.g., South Korea, Thailand, and Turkey) have established special tourism police units to deal with security issues. The police culture and police service quality play important roles in determining tourist safety expectations and perceptions of destinations (Tyagi, Dhar, and Sharma, 2016). Generally, the safety management of tourism enterprises, such as pre-flight safety announcements on airlines 
(Chia-Chen, Wang, and Hsu, 2018), safety and security systems in hotels (Chan and Lam, 2013), and crisis management plans of tourist attractions (Rittichainuwat, 2013), improve safety perceptions of destinations. Thus, PSM describes the safety expectations and perceptions regarding the organizational safety practices within destinations.

\section{Scale Development}

With the guidance of the scale development procedures of Churchill (1979), this research employed a mixed-method design to prepare the TPSD scale. A reliable and valid measurement for TPSD was developed based on three stages (Figure 1).

[Insert Figure 1 about here]

\section{Stage 1: Theme Identification and Item Generation}

Since an adequate conceptual model and measurement scale for TPSD did not exist, a literature review and content analysis of travel blogs assisted with identifying the dimensions and generating initial items for a TPSD scale (Table 1).

[Insert Table 1 about here]

First Initial Item Pool

A broad review of the literature about TPSD was done to generate the first initial item pool for the measurement of TPSD. According to the 4M analysis framework, the current research treated TPSD as a multidimensional construct with five dimensions: PSH, PSFE, PSNE, PSSE, and PSM. Table 2 summarizes the previous research relevant to TPSD items based on these dimensions. Seventeen themes and 29 items were identified and 
grouped into the five dimensions for measuring TPSD from the perspectives of safety system theory and the $4 \mathrm{M}$ analysis framework. For each dimension, the number of themes varied from two to eight, with three themes and six items for PSH (tour guides, residents, and tourism operators); three themes and seven items for PSFE (fully equipped, professional facilities, and good quality); two themes and two items for PSNE (weather and landscape); four themes and eight items for PSNE (transportation, sanitation, consumption safety, and public safety); and five themes and seven items for PSM (emergency plan, emergency evacuation, warning system, safety communication, and police capability).

[Insert Table 2 about here]

\section{Second Initial Item Pool}

The rapid development of Internet technology enables individuals to share their travel-related opinions, experiences, and concerns on online platforms ( $\mathrm{Li}, \mathrm{Law}, \mathrm{Vu}, \mathrm{Jia}$, and Zhao, 2015). Travel blogs represent user-generated content (UGC), which clearly reflects tourist spatial movements, emotional experiences, and safety perceptions in an easily recordable and non-intrusive manner. The second initial item pool was developed through the content analysis of travel blogs from Ctrip, the most influential online travel community in China, to supplement the first item pool. The platform is host active, large, has loyal user groups, and features high levels of openness and significant user interaction; it provides a convenient venue for researchers to observe, extract, and analyze travelers' contextual information about their trips. Travel blogs from Ctrip were 
extracted as a dataset, meeting three screening criteria: (1) to assure the integrity of travel blogs and present tourist safety perceptions through the whole process of tourism, and blogger information on gender, destinations, and means of travel was required; (2) to ensure the representativeness and content quality of selected blogs. Blogs with high reading levels (more than 3,000 reads) ensured content quality and had enough attention; and (3) were posted by genuine tourists and were not blogs sponsored and recommended by websites and destinations. Thereby, 12 blogs of Chinese domestic travelers were selected, including destinations such as Xinjiang, Fujian, Shanghai, Xi'an, Yunnan, and Hainan, and 14 blogs of Chinese outbound travelers were selected, including destinations such as Thailand, France, India, USA, and Australia. There were eight blogs written by males and 18 blogs from females. These 26 blogs had a total of more than 300,000 words, were posted online in 2012, and involved independent travel and group tours.

Additionally, the 26 blogs were coded independently, with C1-C21 for coding and C22-C26 for saturation testing (Table 3).

[Insert Table 3 about here]

Using NVivo-11, the second initial item pool was developed through the three steps of coding, refinement, and generation. Words, phrases, and sentences that reflected TPSD were coded and labeled. An initial coding set with 194 labels was developed after cross-checking with the literature and labels. In the refinement step, the initial coding set was simplified, classified, and integrated according to the proposed TPSD dimensions (human, facility and equipment, natural environment, social-cultural context, and 
management), thereby forming normative concepts that reflected safety perceptions. In the generation step, the normative concepts were re-simplified, re-classified, and re-integrated, and corresponding measurement items of TPSD were developed. During the refinement and generation steps, two researchers, one with a research background in tourism safety and the other familiar with content analysis, independently read and checked the process of coding refinement and item generation. The consistency rate in coding refinement and transcription was 90\%. Finally, the coding set of 194 labels was narrowed down to 21 normative concepts, and 16 new items were generated and added to the first item pool (Table 5). The results of the content analysis added five additional themes to the results of the literature review (natural disasters, political instability, other tourists, and convenience and comfort, Table 4). After the content analysis of the blogs of C21-C26, no new insights were found compared with the previous 21, implying the saturation of the results of the content analysis.

[Insert Table 4 and Table 5 about here]

\section{Content Validity}

The content validity of initial items was assessed in three steps (Table 6). First, an expert panel of three tourism researchers and two senior tour guides independently identified and classified the items with similar measurement scenarios or connotations. The three researchers had more than five years of research experience in tourism safety and destination marketing, and the two senior tour guides had more than five years of industry working experience. Based on the agreement of all experts, 27 items with similar 
connotations were combined into 11 items (e.g., a first aid kit in a hotel room; a flashlight in a hotel room). Second, the remaining 28 items were sorted. According to the realities that Chinese tourists might encounter at destinations, three experts independently sorted the items on each dimension. Three items with relatively low probabilities were excluded (e.g., using public transport is safe) and at least five items for each dimension were guaranteed. Third, the communication quality of each item was optimized. In order for tourists to better understand the items, two experts (one Chinese professor and one British professor) optimized the expressions of items, and seven items were revised without greatly modifying their meanings (e.g., has good infrastructure (communication service, etc.). A pilot test was conducted to assess the effectiveness of item expressions in Fujian Province. In short interviews with 100 respondents after completing questionnaires, no obvious problems and misunderstandings were identified. Finally, 25 initial items were generated and grouped into the five dimensions, with five items for each dimension.

[Insert Table 6 about here]

\section{Stage 2: Scale Refinement}

The purpose of stage 2 was to purify and refine the items generated in stage 1 . Through convenience sampling, data were collected at five popular tourist sites, namely Overseas Chinese Town (Shenzhen), Chimelong Tourist Resort (Guangzhou), Yuntai Mountain (Jiaozuo), Longmen Grottoes (Luoyang), and Qingming Riverside Landscape Garden (Kaifeng). The questionnaires were delivered in a one-to-one format (one respondent and one researcher) and collected on-site to ensure data validity. Respondents were informed 
about the research purpose and anonymity of answers was assured. They rated each item on five-point Likert scales ranging from one (strongly disagree) to five (strongly agree). A total of 350 questionnaires were handed out and 300 valid copies were obtained, representing a valid response rate of $85.7 \%$. The demographic profile of respondents is reported in Table 7.

The internal reliability of the TPSD scale was examined using SPSS 22.0. The item-to-total correlation (ITTC) was computed to identify the reliability of each item, and the results showed that the ITTC of each item was greater than the recommended value of 0.5 (Bagozzi, 1981). Also, the Cronbach's alpha for each construct surpassed the 0.7 threshold, indicating the acceptable reliability of the TPSD scale and its dimensions (Guilford, 1965).

[Insert Table 7 about here]

An explanatory factor analysis (EFA) with principal component analysis and Varimax rotation was conducted. The Kaiser-Meyer-Olkin index was $0.925(>0.7)$ and the Bartlett spherical test was significant at the level of 0.001 , which justified the use of EFA. After seven iterations, five factors with eigenvalues greater than one were extracted, and the cumulative variance contribution was $66.3 \%$. According to Straub's (1989) suggestions, two items with factor loadings below 0.5 were eliminated (PSNE-01; PSNE-02), and the EFA was performed with the remaining 23 items. Finally, five factors were extracted, and both the factor loadings and communities of each item surpassed the cut-off value of 0.5 , accounting for $68.5 \%$ of total variance (Table 8 ). 
[Insert Table 8 about here]

\section{Stage 3: Scale Validation}

\section{Reliability and Validity Assessment}

Confirmatory factor analysis (CFA) in stage 3 was performed to re-examine the factor structure produced from stage 2 , and to verify the convergent and discriminant validity of the TPSD scale. The cross-validity and criterion-related validity of the scale were also examined. In order to improve the representativeness of the sample, stage 3 collected data from the main geographical areas of eastern (Fujian, Taiwan and Zhejiang), northern (Shanxi), central (Hunan), southern (Hong Kong and Macao), southwest (Yunnan and Chongqing), northwest (Inner Mongolia, Shanxi and Ningxia) and northeast (Jilin) regions of China in three time periods. Undergraduate students were employed to deliver questionnaires through convenience sampling in 4A- and 5A-rated tourist attractions during the three summer vacations of 2013, 2015, and 2017. Each undergraduate student was trained to fully understand the research purpose, target groups and anonymity conditions. Also, the questionnaires were required to be delivered in a one-to-one format (one respondent and one researcher) and collected on-site. Eventually, 1,000 questionnaires were distributed in August 2013; 500 questionnaires in August 2015; and 500 questionnaires in August 2017. A total of 2,000 questionnaires were handed out and 1,830 valid responses from 34 provinces of China were obtained, representing an overall valid response rate of $91.5 \%$. The demographic profile of the respondents is in Table 7.

To avoid the self-validation concern, the sample was randomly split into two 
915-case subsamples before performing the CFA. One sample was a calibration sample for modifying the model, while the other was a validation sample for retesting the model. CFA with maximum-likelihood analysis (ML) and the calibration sample was performed using AMOS 22.0 to assess the overall fit of the model. The Cronbach's alpha of each dimension ranged from 0.758 to 0.836 , implying good reliability of the TPSD scale. To achieve construct validity, the convergent, discriminant, and nomological validities need to be considered. For convergent validation, closely following the guidance of Bagozzi (1981) and Hair, Anderson, Tatham, and Black (2010), the goodness-of-fit-indices of the model were adjusted with the following criteria: (1) the standardized factor loadings of each item surpassed 0.5 and were statistically significant at the level of 0.05 ; (2) the composite reliability (CR) of each dimension exceeded the recommended 0.7 threshold; and (3) the average variance extracted (AVE) of each dimension was above the cut-off value of 0.5. With the model modification indices, three items (PSH-0.5, PSFE-04, PSM-01) were eliminated to achieve a better factor structure $\left(\chi^{2}=627.969, d f=160, \chi^{2} / d f\right.$ $=3.925, p=0.000, \mathrm{GFI}=0.933, \mathrm{RMR}=0.034, \mathrm{RMSEA}=0.057, \mathrm{NFI}=0.922, \mathrm{CFI}=$ 0.940, and AGFI $=0.912$ ).

[Insert Table 9 about here]

For discriminant validity, the correlation coefficients between constructs should be less than 0.85 and should be lower than the square root of the average extracted variances (AVEs) of each construct. Table 10 shows that each construct satisfied this requirement, implying a strong discriminant validity of the TPSD scale (Kam and Petrick, 2010). As 
indicated by the correlation matrix (Table 10), the five constructs of the TPSD scale were all correlated at the significance level of 0.01 , which confirmed the predictability of each construct at the theoretical level and demonstrated nomological validity.

[Insert Table 10 about here]

\section{Model Comparison of TPSD}

Four competitive models were constructed with the validation sample to identify the optimal factor structure for TPSD (Figure 2). Model 1 was a one first-order factor model with 20 items (Figure 2-1); model 2 was a five first-order factor model without correlation (Figure 2-2); model 3 was a five first-order factor model with correlation (Figure 2-3), and model 4 was a one second-order factor model with five first-order factors (Figure 2-4).

As shown in Table 11, the goodness-of-fit of model 1 and model 2 did not meet the recommended level, implying that both model 1 and model 2 were not the optimal measurement structure for TPSD. Additionally, model 3 and model 4 showed better goodness-of-fit than model 1 and model 2, and the two models also demonstrated satisfactory fit. However, model 3 was superior to model 4. In model 4, the loadings of the initial five factors (PSH, PSFE, PSNE, PSSE, PSM) on the second order TPSD were $0.751,0.816,0.682,0.760$, and 0.765 , which exceeded the recommended 0.5 threshold and were statistically significant at the level of 0.01 . This dimensionality test suggested that model 3 was the optimal factor structure for TPSD (Figure 2-3) and supported the use of a second-order measurement structure for TPSD as well (Figure 2-4). 
[Insert Table 11 and Figure 2 about here]

\section{Cross Validity}

An invariance test was employed to assess the cross-validity of the TPSD scale. An invariance test across randomly selected groups (50\% vs. 50\%) was performed. Table 12 shows that the baseline model for the unconstrained model and the factor loading constrained model indicated a satisfactory overall fit and the same construct was measured across specified groups. The result of the chi-square difference test between the randomly selected samples was invariant $\left(\Delta \chi^{2}(\Delta d f=15)=16.311, p=0.362>0.05\right)$. These aforementioned results determined that the measurement model was invariant across different groups, and the cross-validity of the five-dimensional structure of the TPSD scale was confirmed as well.

\section{[Insert Table 12 about here]}

\section{Criterion Validity}

The criterion validity of the TPSD scale can be confirmed by the correlation with relevant scales. George's (2003) scale of tourist perceptions of safety and security (TPSS) and Edmondson's (1999) scale of psychological safety (PS) were most influential measurements in relation to the TPSD. Thus, seven items measuring TPSS adapted from George (2003), and six items measuring PS adapted from Edmondson (1999) were included in the questionnaire together with the developed TPSD scale. Each item was anchored on a Likert five-point scale, ranging from one (strongly disagree) to five (strongly agree) based on travel experiences. As shown in Table 13, the Cronbach's alpha 
values of TPSS and PS surpassed the cut-off value of 0.7, and TPSD and its dimensions were found to be positively correlated with TPSS and PS. Also, the correlation coefficients between TPSD (second order) and TPSS and PS were stronger than their dimensions. Thus, the criterion-related validity of the TPSD scale was verified.

\section{[Insert Table 13 about here]}

\section{Conclusions and Implications}

\section{Conclusions}

Strictly following the procedures proposed by Churchill (1979), this research provides a reliable conceptualization and valid scale for TPSD based on safety system theory. A three-stage study was conducted and a 20-item, five-dimension (PSH, PSFE, PSNE, PSSE, PSM) TPSD scale received support. The TPSD scale passed a reliability test, EFA and CFA, and confirmed that the measurement model proposed for TPSD was applicable to a first-order factor as well as a second-order factor model. Additionally, the convergent, discriminant, nomological, cross, and criterion validities were confirmed.

The results indicated that there were dimensional differences in the perceived level of destination safety among Chinese tourists. According to Table 9, PSH (mean = 3.76) and PSFE (mean $=3.82)$ were relatively high and included the major high-scoring items (PSFE-03, 05; PSH-03, 04), and PSNE (mean = 3.65) and PSSE (mean = 3.56) were relatively low and covered major low-scoring items (PSNE-04, 05; PSSE-01, 02, 03). Additionally, the loadings of the initial five factors (PSH, PSFE, PSNE, PSSE, and PSM) on the second order TPSD were $0.751,0.816,0.682,0.760$, and 0.765 , implying the 
category differences in the TPSD of Chinese tourists.

\section{Theoretical implications}

First, the current study compensates for the deficit in the existing literature by conceptualizing and verifying TPSD as a multi-dimensional construct based on safety system theory. Safety is a basic need of tourists and it is also recognized as being a fundamental condition for the sustainable development of destinations. Previous studies have investigated and measured TPSD in the contexts of crime, roads, safety and security

measures (Wilks et al., 1999; Choocharukul and Sriroongvikrai, 2017; Rittichainuwat and Chakraborty, 2002; George, 2003; 2010), and may have a certain degree of measurement bias. Tourist personal assessments of safety elements and information at destinations constitute TPSD (Seabra et al., 2013). Obviously, this element varies in nature, type, and source, and thus it is imperative to explore the conceptualization and measurement structure of TPSD from a systems structure perspective. Accordingly, the conceptualization and hierarchical level sources of TPSD (human, facility and equipment, environment, and management) were identified based on safety system theory and the 4M analysis framework, which provide clearly structured and inclusive dimensions of perceived safety for tourism research.

Second, this research proposes that TPSD can be regarded as tourist perceptions of the "travel safety system" and it integrates assessments of the risk-induced factors of the accident system and the elements of the safety system. This research is the first occasion for safety system theory to be applied to measure tourist safety perceptions. Specifically, 
the 4Ms are the basic risk factors and safety elements in safety and accident systems, and the $4 \mathrm{M}$ analysis framework uncovers the structure that underlines the safety perceptions and experiences of tourists from a risk-source perspective, as well as representing safety perception structures at destinations (Bentley et al., 200; Page et al., 2005; Xie et al., 2020). According to the literature review and risk situations faced by tourists, the environmental elements perceived by them can be subdivided into natural and social-cultural environmental safety dimensions (Scott and Lemieux, 2010; Freitas, 2010; Mansfeld et al, 2004; Pizam and Smith, 2000; Sönmez and Graefe, 1998; Jenkin, 2006). The results showed that the human and facility elements were of greatest concern, while the natural and social elements had lesser scores in the TPSD system, which reflects the differing evaluations of tourists of safety at destinations. Therefore, this research expands the concept of environments in safety system theory and the $4 \mathrm{M}$ analysis framework and provides new insights into the effects of diverse elements during the formation of TPSD.

Third, the new scale advances the knowledge of TPSD by providing a reliable and valid measurement tool for follow-up empirical research. The measurement of TPSD has received much attention by academic scholars, and various measurement structures of TPSD have been proposed. This TPSD scale is rooted in safety system theory and the 4M analysis framework, which assures that measurements are systematic, hierarchical, and universal. The TPSD scale covers various types of safety elements that may affect tourist safety assessments, which include some of the dimensions of TPSD, for example that of safety elements from the environmental level such as crime (George, 2003; 2010), and 
natural disasters (Rittichainuwat, 2013). The safety elements from the facility and equipment level such as security equipment (Rittichainuwat and Chakraborty, 2002) are scattered across previous research. Safety elements from human and management levels have rarely been discussed in tourism research. Compared with previous scales, the newly proposed TPSD scale embeds tourist safety assessments in the generalized travel context and with a location orientation. Multiple subjects, varied elements, and diverse situations to which tourists may be exposed were taken into consideration to systematically measure the safety perception structure of tourists.

\section{Practical Implications}

This research has several practical implications. First, destination management organizations (DMOs) should use the TPSD scale for a better understanding of safety perceptions, and subsequently for developing tailored strategies to maintain a safe destination environment for tourists based on each specific dimension. For example, DMOs should incorporate the behavior of tour guides, residents, tourism operators, and even the tourists themselves into the scope of human safety management. DMOs should enhance the comprehensive management of facilities and equipment, particularly in the context of consumption and recreation. The regular inspection of performance, convenience, and availability of facilities and equipment should be guaranteed as well. DMOs should divide the environmental safety system into two sub-components (natural environment and social-cultural contexts) to improve the professionalism of natural and social environmental safety management. For management safety elements, DMOs 
should pay attention to the development of professional safety programs and strengthen the preparation of crisis management plans, security work, safety resources, and safety culture at the destination level. Additionally, DMOs should strengthen the interaction between tourists and these safety elements, thereby enhancing the travel and safety confidence of people in unfamiliar environments.

Second, the scale can be used to assess the perceived safety levels of tourists, and thus become a benchmark for DMOs for image and crisis management. The scale can be used as a diagnostic tool to continuously monitor changes in tourist safety perception levels and provide decision support for optimizing destination safety image management practices. Even after a crisis, the scale need not only be used to identify the elements that influenced tourist safety assessments, but also clearly will reflect the effectiveness of destination safety management in crisis situations, thereby guiding the inclusion of further tailored measures and services. In addition, DMOs should categorize crisis situations and based on the dimensional and element differences in tourist safety perceptions after crisis events. DMOs should establish an information intervention system for major information channels for tourists during a crisis and reduce the negative impacts through the emergency responses of multiple subjects, such as local governments, residents, tourism operators, and tourists.

Third, this research also indicates that the scores of Chinese tourists on PSFE (Mean $=3.82)$, PSH $($ Mean $=3.76)$, PSM $($ Mean = 3.75), PSNE $($ Mean $=3.65)$, and PSSE $($ Mean $=3.56)$ decreased in order, and the scores on environmental safety perception 
were the lowest. These results show that DMOs in China should improve the safety knowledge and skills of tour guides. Also, DMOs in China should promote the reliability of facilities and equipment in operations, as well as provide enough safety equipment. It is of great concern that tourist safety perceptions of natural and social-cultural environments are low. DMOs in China should not only mitigate the negative impact on TPSD of natural disasters, but also strictly address the social-cultural issues such as overcrowding, scams and frauds, theft, violence, and forced shopping.

\section{Limitations and Directions for Future Research}

The current research has some limitations that may be remedied by future studies. First, although safety system theory provides clearly structured and inclusive dimensions of TPSD, this theory was developed in a non-travel context. Thus, safety system theory cannot capture the essential essence of tourism, such as movement, unfamiliar environments, and the TPSD items developed are frequently connected to accidents and perceptions of tourist safety. Future research should adopt diverse theoretical perspectives, especially those closely related to tourism to confirm and optimize the TPSD scale.

Second, some items developed may not be universal enough, and the items related to the PSFE dimension may seem somewhat unclear. Thus, future refinement of the TPSD scale items is warranted. Third, the measurement structure of TPSD was developed only for Chinese tourists, and tourists with different cultural backgrounds may have different understandings of some items. To ensure the universality of the TPSD scale, future research should expand sample sizes and explore TPSD in different cultural contexts. 
Fourth, the data were collected through convenience sampling. Since the survey was conducted during summer vacations, youth/students accounted for a large proportion of the whole sample. Tourist characteristics, such as age and occupation, have an impact on perceived safety. Future studies should validate the TPSD scale with different research designs and samples, as well as investigating the effect of tourist characteristics (e.g., age, occupation) on TPSD. Fifth, the criterion validity of the TPSD scale was confirmed by the correlations with the relevant scales of George (2003) and Edmondson (1999). The antecedents (e.g., destination image, destination safety atmosphere) and consequences (e.g., tourist satisfaction, safety behavior, revisit intention) of TPSD should be investigated in future studies.

\section{References}

Alegre, Joaquín, Mateo, S., and Pou, L. 2013. "Tourism participation and expenditure by Spanish households: the effects of the economic crisis and unemployment." Tourism Management 39: 37-49.

Amir, A. F., Ismail, M. N. I., and See, T. P. 2015. "Sustainable tourist environment: perception of international women travelers on safety and security in Kuala Lumpur." Procedia - Social and Behavioral Sciences 168: 123-133.

Bagozzi R P. 1981. Evaluating Structural Equation Models with Unobservable Variables and Measurement Error: A Comment." Journal of Marketing Research 18 (3): $375-381$.

Becken, S., and Hughey, K. F. 2013. "Linking tourism into emergency management 
structures to enhance disaster risk reduction." Tourism Management 36: 77-85.

Bentley, T., Page, S., Meyer, D., Chalmers, D., and Laird, I. 2001. "How safe is adventure tourism in New Zealand? An exploratory analysis." Applied Ergonomics 32 (4): $327-338$.

Boakye K A. 2012. “Tourists' views on safety and vulnerability. A study of some selected towns in Ghana." Tourism Management 33 (2): 327-333.

Breitsohl, J., and Garrod, B. 2016. “Assessing tourists' cognitive, emotional and behavioural reactions to an unethical destination incident." Tourism Management 54: 209-220.

Caber, M., and Albayrak, T. 2016. “Assessing daily tour service quality: a proposal for a dailyserv scale.” Journal of Destination Marketing \& Management 7: 18-25.

Cavlek, N. 2002. "Tour operators and destination safety." Annals of Tourism Research 29 (2): 478-496.

Chan, E. S. W., and Lam, D. 2013. "Hotel safety and security systems: bridging the gap between managers and guests." International Journal of Hospitality Management 32: 202-216.

Chauhan, V. 2007. "Safety and security perceptions of tourists visiting Kashmir, India." Advances in Hospitality and Leisure 3: 3-17.

Chen, C. F. 2007. "How destination image and evaluative factors affect behavioral intentions?” Tourism Management 28 (4): 1115-1122.

Chen, W. 2014. "A quantitative fuzzy causal model for hazard analysis of 
man-machine-environment system." Safety Science 62 (2): 475-482

Chi, G. Q., and Qu, H. 2008. "Examining the structural relationships of destination image, tourist satisfaction and destination loyalty: an integrated approach." Tourism Management 29 (4): 624-636.

Chia-Chen, L., Wang, S. W., Hsu, M. K., and Shih-Ming, J. 2018. “Air passenger's perception toward pre-flight safety briefing videos: does it matter?" Journal of Air Transport Management 72: 20-31.

Choocharukul, K., and Sriroongvikrai, K. 2017. "Road Safety Awareness and Comprehension of Road Signs from International Tourist's Perspectives: A Case Study of Thailand." Transportation Research Procedia 25: 4518-4528.

Churchill, G. A. 1979. “A Paradigm for Developing Better Measures of Marketing Constructs." Journal of Marketing Research 16 (1): 64-73.

Coxon, C. 2006. "Safety in the dive tourism industry of Australia." In J. Wilks, D. Pendergast, and P. Leggat (Eds.), Tourism in turbulent times: Towards safe experiences for visitors (pp. 199-215). Amsterdam: Elsevier.

Echtner C M, Ritchie J R B. 1993. “The Measurement of Destination Image: An Empirical Assessment." Journal of Travel Research 31 (4): 3-13.

Edmondson A. 1999. "Psychological Safety and Learning Behavior in Work Teams." Administrative Science Quarterly 44 (2): 350-383.

Edwards, E. 1972. "Man and machine: systems for safety.” In: Proceedings of British Airline Pilots Association Technical Symposium. British Pilots Association, London, 
pp. 21-36.

Eitzinger, C., and Wiedemann, P. 2007. "Risk perceptions in the alpine tourist destination Tyrol: An exploratory analysis of residents' views." Tourism Management 28 (3): 911-916.

Fischhoff, B., Watson, S. and Hope, C. (1984). "Defining risk.” Policy Sciences 17: 123-139.

Fourie, J., Rossello-Nadal, J., and Santana-Gallego, M. 2020. "Fatal attraction: How security threats hurt tourism", Journal of Travel Research 59 (2): 209-219.

Freitas, C. R. D. 2010. "Recreation climate assessment.” International Journal of Climatology 10 (1): 89-103.

Gartner, W. C., and Shen, J. 1992. "The impact of Tiananmen square on China's tourism image." Journal of Travel Research 30 (4): 47-52.

George, R. 2003. "Tourist's perceptions of safety and security while visiting Cape Town." Tourism Management 24 (5): 575-585.

George, R. 2010. "Visitor perceptions of crime-safety and attitudes towards risk: the case of Table Mountain national park, Cape town." Tourism Management 31 (6): $806-815$

Guilford, J. P. 1965. "Fundamental Statistics in Psychology and Education (4th ed)." New York: Mc Graw-Hill.

Gurtner, Y. 2016. "Returning to paradise: Investigating issues of tourism crisis and disaster recovery on the island of Bali." Journal of Hospitality and Tourism 
Management 28: 11-19.

Hair, J. F., Anderson, R. E., Tatham, R. L., and Black, W. C. 2010. "Multivariate Data Analysis: A Global Perspective 7 Pearson.” Upper Saddle River: NJ.

Hosany, S., Ekinci, Y., and Uysal, M. 2007. "Destination image and destination personality." International Journal of Culture, Tourism \& Hospitality Research 1 (1): $62-81$

Hübner, A., and Gössling, S. 2012. "Tourist perceptions of extreme weather events in Martinique." Journal of Destination Marketing \& Management 1 (1-2): 47-55.

Jamot, D. G. C., and Park, J. Y. 2019. "System theory based hazard analysis for construction site safety: A case study from Cameroon.” Safety science 118: 83-794.

Jenkin, C. M. 2006. "Risk Perception and Terrorism: Applying the Psychometric Paradigm." Homeland Security Affairs 2 (2): 1-14.

Kam H, Petrick J F. 2010. "Developing a measurement scale for constraints to cruising." Annals of Tourism Research 37 (1): 206-228.

Kapuściński, Grzegorz, and Richards, B. 2016. "News framing effects on destination risk perception." Tourism Management 57: 234-244.

Kılıçlar, A., Uşaklı, A., and Tayfun, A. 2018. "Terrorism prevention in tourism destinations: Security forces vs. civil authority perspectives." Journal of Destination Marketing \& Management 8: 232-246.

Koo, T. T. R., Collins, A. T., Williamson, A., and Caponecchia, C. 2019. "How safety risk information and alternative forms of presenting it affect traveler decision rules in 
international flight choice." Journal of Travel Research 58 (3): 480-495.

Lee, Y., Pennington-Gray, L., and Kim, J. 2019. "Does location matter? Exploring the spatial patterns of food safety in a tourism destination." Tourism Management 71: $18-33$.

Leveson, N. 2004. "A new accident model for engineering safer systems." Safety Science 42 (4): $\quad 237-270$.

Leveson, N. 2011. "Engineering a Safer World: Systems Thinking Applied to Safety." MIT Press.

Li, G., Law, R., Vu, H. Q., Jia, R., and Zhao, X. Y. 2015. “Identifying emerging hotel preferences using emerging pattern mining technique." Tourism Management 46: $311-321$

Li, W., Zhang, L., and Liang, W. 2017. "An accident causation analysis and taxonomy (ACAT) model of complex industrial system from both system safety and control theory perspectives." Safety Science 92, 94-103.

Li, X. (Eds). 2016. “Chinese outbound tourism 2.0.” Waretown, NJ: Apple Academic Press/CRC Press- Taylor \& Francis Group.

Loewenstein, G. F., Hsee, C. K., Weber, E. U., and Welch, N. 2001. "Risk as feelings." Psychological Bulletin 127(2), 267-286.

Lower, M., Magott, J., and Skorupski, J. 2018. "A system-theoretic accident model and process with human factors analysis and classification system taxonomy." Safety science 110: 393-410. 
MacLaurin, T. L. 2004. "The importance of food safety in travel planning and destination selection.” Journal of Travel and Tourism Marketing 15 (4): 233-257.

Maguire, E. R., and Johnson, D. 2010. "Measuring public perceptions of the police." Policing: An International Journal of Police Strategies \& Management 33 (4): $703-730$

Mansfeld, Y., Freundlish, A., and Kutiel, H. 2004. "The relationship between weather conditions and tourist's perception of comfort: The case of the winter sun resort of Eilat. In B. Amelung, and D. Viner (Eds.)" Proceedings of the NATO advanced research workshop on climate change and tourism. Warsaw, Poland.

Mao, Y., and Xu, T. 2011. "Research of $4 \mathrm{~m} 1 \mathrm{e}$ 's effect on engineering quality based on structural equation model.” Systems Engineering Procedia 1: 213-220.

Miller, C. O. 1991. "Investigating the management factors in an airline accident." Hydrological Processes 22 (17): 3418-3430.

Mitchell, V. W., and Greatorex, M. 1993. "Risk perception and reduction in the purchase of consumer services." The Service Industries Journal 13 (4): 179-200.

Okuyama, T. 2018. "Analysis of optimal timing of tourism demand recovery policies from natural disaster using the contingent behavior method." Tourism Management 64: $37-54$

Page, S. J., Bentley, T. A., and Walker, L. 2005. "Scoping the nature and extent of adventure tourism operations in Scotland: how safe are they?" Tourism Management 26 (3): 381-397. 
Park, K., and Reisinger, Y. 2010. "Differences in the perceived influence of natural disasters and travel risk on international travel." Tourism Geographies 12 (1): 1-24.

Patwardhan, P., Ribeiro, M. A., Payini, V., Woosnam, K. M., Mallya, J., and Gopalakrishnan, P. 2020. "Visitors' place attachment and destination loyalty: Examining the roles of emotional solidarity and perceived safety." Journal of Travel Research 59 (1): 3-21.

Peccei, R., and Rosenthal, P. 2000. "Front-line responses to customer orientation programmes: a theoretical and empirical analysis." The International Journal of Human Resource Management 11 (3): 562-590.

Pizam, A., and Smith, G. 2000. "Tourism and terrorism: a quantitative analysis of major terrorist acts and their impact on tourism destinations." Tourism Economics 6(2): $123-138$.

Putra, K. D. 2010. “Image restoration strategy of Bali tourism crises.” The Journal of Communication Sciences 5 (1): 71-88.

Rasmussen, J., and Suedung, I. 2000. "Proactive risk management in a dynamic society." Swedish Rescue Services Agency.

Rittichainuwat, B. 2008. "Responding to disaster: the case study of Phuket, Thailand." Journal of Travel Research 46 (4): 422-432.

Rittichainuwat, B. N., and Chakraborty, G. 2012. "Perceptions of importance and what safety is enough." Journal of Business Research 65 (1): 0-50.

Rittichainuwat, B. N., 2013. “Tourists' and tourism suppliers' perceptions toward crisis 
management on tsunami." Tourism Management 34: 112-121.

Ryan, C. 2003. "Risk acceptance in adventure tourism-Paradox and context." In J. Wilks, and S. J. Page (Eds.), Managing tourist health and safety in the new millennium. Oxford: Pergamon.

Scott, D., and Lemieux, C. 2010. "Weather and climate information for tourism." Procedia Environmental Sciences 1 (1): 146-183.

Seabra, C., Dolnicar, S., Abrantes, J., and Kastenholz, E. 2013. "Heterogeneity in risk and safety perceptions of international tourists." Tourism Management 36: 502-510.

Sharifpour, M., Walters, G., Ritchie, B. W., and Winter, C. 2014. "Investigating the role of prior knowledge in tourist decision making: a structural equation model of risk perceptions and information search." Journal of Travel Research 53 (3): 307-322.

Sheldon, P. J., and Fox, M. 1988. "The role of foodservice in vacation choice and experience: A Cross-Cultural analysis.” Journal of Travel Research 27 (2): 9-15.

Sierra, F. J. M., Rubio-Romero, J. C., and Gámez, M. C. R. 2012. "Status of facilities for fire safety in hotels." Safety science 50 (7): 1490-1494.

Smith, V. L. 1998. "War and tourism: An American ethnography." Annals of tourism research 25 (1): 202-227.

Song, X., and Xie, Z. 2014. "Application of man-machine-environment system engineering in coal mines safety management." Procedia Engineering 84 (2): 87-92

Sönmez, S. F., and Graefe, A. R. 1998. "Determining future travel behavior from past travel experience and perceptions of risk and safety." Journal of Travel Research 37 
(2): 171-177.

Sönmez, S., and Graefe, A. 1998. "Influence of terrorism risk on foreign tourism decisions." Annals of Tourism Research 25 (1): 112-144.

Straub D W. 1989. "Validating Instruments in MIS Research.” MIS Quarterly 13 (2):147-169.

Tsaur, S. H., Cheng, T. M., and Hong, C. Y. 2019. Exploring tour member misbehavior in group package tours. Tourism Management 71: 34-43.

Tutuncu, and Ozkan. 2017. "Investigating the accessibility factors affecting hotel satisfaction of people with physical disabilities." International Journal of Hospitality Management 65: 29-36.

Tyagi, A., Dhar, R. L., and Sharma, J. 2016. "Police culture, tourists and destinations: A study of Uttarakhand, India.” Tourism Management 52: 563-573.

UNWTO. 2018. "UNWTO tourism highlights 2018 edition.” Madrid, Spain: UN World Tourism Organization.

Utz, S., Schultz, F., and Glocka, S. 2013. “Crisis communication online: How medium, crisis type and emotions affected public reactions in the Fukushima Daiichi nuclear disaster." Public Relations Review 39 (1): 40-46.

Wang, K. C., Hsieh, A. T., Chou, S. H., and Lin, Y. S. 2007. “GPTCCC: An instrument for measuring group package tour service.” Tourism Management 28 (2): 361-376.

Wang, K.-C. Jao, P. C., Chan, H.-C., and Chung, C.-H. 2010. Group package tour leader's intrinsic risks." Annals of Tourism Research 37 (1): 154-179. 
Weber, E. U., and Johnson, E. J. 2009. Decisions under uncertainty: Psychological, economic, and neuroeconomic explanations of risk preference. In Neuroeconomics: Decision Making and the Brain, P. W. Glimcher, Camerer, C. F., Fehr, E., and Poldrack, R. A. (Eds.), pp. 127-144. London, England: Academic Press.

Wildavsky A., and Dake K. 1990. "Theories of risk perception: Who fears what and why?" Daedalus 119(4), 41-60.

Wilks, J., Watson, B., and Faulks, I. J. 1999. "International tourists and road safety in Australia: developing a national research and management programme." Tourism Management 20 (5): 645-654.

Williams, A. M., and Baláž V. 2013. “Tourism, risk tolerance and competences: travel organization and tourism hazards." Tourism Management 35: 209-221.

Woosnam, K. M., Shafer, C. S., Scott, D., and Timothy, D. J. 2015. “Tourists' perceived safety through emotional solidarity with residents in two Mexico-United States border regions." Tourism Management 46: 263-273.

Xie, C., Zhang, J., Chen, Y., Morrison, A. M., and Lin, Z. 2020, “Measuring hotel employee perceived job risk: dimensions and scale development." International Journal of Contemporary Hospitality Management 32 (2): 730-748.

Yuksel, A. 2004. "Shopping experience evaluation: a case of domestic and international visitors." Tourism Management 25 (6): 751-759. 
Table 1. Generation of item pool for measuring TPSD

\begin{tabular}{|c|c|c|c|}
\hline Steps & Purposes & Methods & Outcomes \\
\hline Step 1 & Develop initial items & Literature review & First initial pool: 29 items \\
\hline Step 2 & $\begin{array}{l}\text { Open code: extract the statements containing } \\
\text { TPSD from tourist blogs }\end{array}$ & $\begin{array}{l}\text { 1. Content analysis } \\
\text { (NVivo11) }\end{array}$ & Develop an initial coding set \\
\hline Step 3 & Refine and classify the coding set & 2. Cross-checking & Generate final codes \\
\hline Step 4 & Code the statements into initial items & 3. Literature review & Second initial pool: 16 items \\
\hline Step 5 & Refine items for content validity & Expert assessment & Final initial pool: 25 items \\
\hline
\end{tabular}


Table 2. Dimensions and initial items of TPSD

\begin{tabular}{|c|c|c|c|c|}
\hline Dimensions & Themes & Original Items & Reference (before 2012) & $\begin{array}{l}\text { Reference (similar } \\
\text { items after 2012) }\end{array}$ \\
\hline \multirow{4}{*}{ PSH } & Tour guide & $\begin{array}{l}\text { The tour leader has a professional ability } \\
\text { The tour leader shows friendliness }\end{array}$ & Wang et al. (2007) & \multirow{2}{*}{$\begin{array}{l}\text { Caber and Albayrak } \\
\text { (2016) }\end{array}$} \\
\hline & Tourism operator & $\begin{array}{l}\text { Put a lot of effort into job try to satisfy } \\
\text { customers. }\end{array}$ & $\begin{array}{l}\text { Peccei and Rosenthal } \\
(2000)\end{array}$ & \\
\hline & \multirow[b]{2}{*}{ Resident } & Hospitable and friendly people & Chen and Tsai (2007) & \multirow[b]{2}{*}{$\begin{array}{l}\text { Akgün, Senturk, } \\
\text { Keskin, Onal, (2019) }\end{array}$} \\
\hline & & Local people are friendly & $\begin{array}{l}\text { Echtner and Ritchie } \\
(1993)\end{array}$ & \\
\hline \multirow{6}{*}{ PSFE } & \multirow{2}{*}{ Fully-equipped } & A first aid kit in hotel room & \multirow{2}{*}{$\begin{array}{l}\text { Rittichainuwat and } \\
\text { Chakrabort (2012) }\end{array}$} & \multirow{2}{*}{ Rittichainuwat (2013) } \\
\hline & & A flashlight in hotel room & & \\
\hline & $\begin{array}{l}\text { Professional } \\
\text { facility }\end{array}$ & $\begin{array}{l}\text { A facemask for each guest for smoke, disease } \\
\text { Walk-in metal detector at the hotel } \\
\text { Continuing airport temperature/thermal check }\end{array}$ & $\begin{array}{l}\text { Rittichainuwat and } \\
\text { Chakrabort (2012) }\end{array}$ & \multirow{4}{*}{$\begin{array}{l}\text { Akgün, Senturk, } \\
\text { Keskin, Onal, (2019) }\end{array}$} \\
\hline & Good quality & Has a good infrastructure (communication & Hosany, Ekinci and & \\
\hline & Jovu quarily & service, etc.) & Uysal (2007) & \\
\hline & & Safety of the coach is reliable & Wang et al. (2007) & \\
\hline \multirow{3}{*}{ PSNE } & Weather & Good weather/pleasant weather & $\begin{array}{l}\text { Chen and Tsai (2007); } \\
\text { Echtner and Ritchie } \\
\text { (1993) }\end{array}$ & \\
\hline & & & Chen and Tsai (2007); & \\
\hline & Landscape & Spectacular landscape & $\begin{array}{l}\text { Hosany, Ekinci and } \\
\text { Uysal (2007) }\end{array}$ & \\
\hline \multirow{7}{*}{ PSSE } & & Driving around city is safe & George $(2003 ; 2010)$ & \multirow{7}{*}{$\begin{array}{l}\text { Lee et al. (2018); } \\
\text { Akgün, Senturk, } \\
\text { Keskin, Onal, (2019) } \\
\text { Caber and Albayrak } \\
\quad(2016)\end{array}$} \\
\hline & Transportation & Local transport engaged to visit tourist places & Chauhan (2007) & \\
\hline & Sanitation & $\begin{array}{l}\text { Local standard of cleanliness and hygiene are } \\
\text { high }\end{array}$ & $\begin{array}{l}\text { Echtner and Ritchie } \\
\text { (1993) }\end{array}$ & \\
\hline & Consumption & Shopping shores have good reputation & Wang et al. (2007) & \\
\hline & safety & A good shopping place & Chen and Tsai (2007) & \\
\hline & \multirow[b]{2}{*}{ Public safety } & $\begin{array}{l}\text { Walking streets after dark is safe } \\
\text { Using public transport is safe }\end{array}$ & George $(2003 ; 2010)$ & \\
\hline & & $\begin{array}{l}\text { Performing leisure activities such as shopping, } \\
\text { adventure, roaming and photography is safe }\end{array}$ & Chauhan (2007) & \\
\hline \multirow{5}{*}{ PSM } & $\begin{array}{l}\text { Emergency plan } \\
\text { Emergency } \\
\text { evacuation }\end{array}$ & $\begin{array}{l}\text { A crisis management plan of service providers } \\
\text { Rehearsal of evacuation plan for emergency }\end{array}$ & $\begin{array}{l}\text { Rittichainuwat and } \\
\text { Chakrabort (2012) }\end{array}$ & \multirow[t]{3}{*}{ Rittichainuwat (2013) } \\
\hline & Warning system & Tsunami warning system on beaches & Rittichainuwat and & \\
\hline & & Evacuation warning system linked to guest room & $\begin{array}{l}\text { Chakrabort (2012) } \\
\text { Fchtner and Ritchie }\end{array}$ & \\
\hline & $\begin{array}{l}\text { Safety } \\
\text { communication }\end{array}$ & Good tourist information is really available & $\begin{array}{l}\text { Echtner and Ritchie } \\
\text { (1993) }\end{array}$ & $\begin{array}{l}\text { Amir et al. (2015) ; } \\
\text { Lee et al. (2018) }\end{array}$ \\
\hline & Police capability & $\begin{array}{l}\text { The police do their job well } \\
\text { Police officers attempt to maintain a safe } \\
\text { environment }\end{array}$ & $\begin{array}{l}\text { Maguire and Johnson } \\
\text { (2010) }\end{array}$ & Tyagi et al.(2016) \\
\hline
\end{tabular}

Note: The first initial item pool was developed and generated in 2012. 
Table 3. Travel blog sample profile

\begin{tabular}{|c|c|c|c|c|c|c|c|c|c|}
\hline No. & Gender & $\begin{array}{l}\text { Travel } \\
\text { group }\end{array}$ & Title & Destination & No. & Gender & $\begin{array}{l}\text { Travel } \\
\text { group }\end{array}$ & Title & Destination \\
\hline $\mathrm{C} 1$ & Male & Alone & Miles to go alone & China & $\mathrm{C} 14$ & Female & Couples & Maldives trip & Maldives \\
\hline $\mathrm{C} 2$ & Male & Alone & Incredible Indian scenery & India & $\mathrm{C} 15$ & Female & Couples & $\begin{array}{l}\text { Independent travel in } \\
\text { North India in New } \\
\text { year }\end{array}$ & India \\
\hline $\mathrm{C} 3$ & Female & Alone & Into Shanghai & China & $\mathrm{C} 16$ & Female & Alone & Yunnan Impressions & China \\
\hline $\mathrm{C} 4$ & Female & $\begin{array}{l}\text { With } \\
\text { family }\end{array}$ & $\begin{array}{l}\text { Travel to Europe with } \\
\text { Mom }\end{array}$ & France & $\mathrm{C} 17$ & Male & $\begin{array}{l}\text { With } \\
\text { friend }\end{array}$ & A deep tour in Yunnan & China \\
\hline $\mathrm{C} 5$ & Female & $\begin{array}{l}\text { Tour } \\
\text { group }\end{array}$ & "Silk Road" Group Tour & China & $\mathrm{C} 18$ & Female & $\begin{array}{l}\text { With } \\
\text { family }\end{array}$ & $\begin{array}{l}7200 \text { kilometers in } 28 \\
\text { days }\end{array}$ & China \\
\hline C6 & Male & Alone & $\begin{array}{l}\text { Fly to South Africa to see } \\
\text { the world }\end{array}$ & $\begin{array}{l}\text { South } \\
\text { Africa }\end{array}$ & $\mathrm{C} 19$ & Female & $\begin{array}{l}\text { With } \\
\text { friend }\end{array}$ & Travel Guide in 2012 & China \\
\hline $\mathrm{C} 7$ & Male & $\begin{array}{l}\text { Tour } \\
\text { group }\end{array}$ & Paradise on Hawaii & USA & $\mathrm{C} 20$ & Female & $\begin{array}{c}\text { With } \\
\text { family }\end{array}$ & Travel in Xi'an & China \\
\hline $\mathrm{C} 8$ & Female & $\begin{array}{l}\text { Tour } \\
\text { group }\end{array}$ & Tips for United States Tour & USA & $\mathrm{C} 21$ & Female & $\begin{array}{l}\text { Tour } \\
\text { group }\end{array}$ & $\begin{array}{l}8 \text { days of Spring } \\
\text { Festival tour in Egypt }\end{array}$ & Egypt \\
\hline C9 & Male & Alone & Bangkok, Thailand & Thailand & $\mathrm{C} 22$ & Female & $\begin{array}{l}\text { With } \\
\text { friend }\end{array}$ & Eden on earth in 2012 & Europe \\
\hline $\mathrm{C} 10$ & Female & $\begin{array}{l}\text { With } \\
\text { family }\end{array}$ & $\begin{array}{l}3500 \mathrm{~km} \text { self-driving tour } \\
\text { in Thailand }\end{array}$ & Thailand & $\mathrm{C} 23$ & Female & $\begin{array}{l}\text { With } \\
\text { friend }\end{array}$ & $\begin{array}{l}\text { Heaven of light and } \\
\text { shadow-Kapalai }\end{array}$ & Malaysia \\
\hline $\mathrm{C} 11$ & Female & $\begin{array}{l}\text { Tour } \\
\text { group }\end{array}$ & $\begin{array}{l}6 \text { days and } 5 \text { nights } \\
\text { (Tokyo, Nagoya, Nara, } \\
\text { Kyoto, Osaka, Japan) }\end{array}$ & Japan & $\mathrm{C} 24$ & Male & Alone & Travel in Sanya & China \\
\hline $\mathrm{C} 12$ & Female & $\begin{array}{l}\text { With } \\
\text { family }\end{array}$ & $\begin{array}{l}\text { A independent tour of } \\
\text { Australia }\end{array}$ & Australia & $\mathrm{C} 25$ & Female & $\begin{array}{l}\text { With } \\
\text { friend }\end{array}$ & $\begin{array}{l}\text { Visiting Dai Temple in } \\
\text { the off-season }\end{array}$ & China \\
\hline $\mathrm{C} 13$ & Female & $\begin{array}{l}\text { With } \\
\text { friend }\end{array}$ & $\begin{array}{l}\text { Self-driving tour on New } \\
\text { Zealand South Island }\end{array}$ & $\begin{array}{l}\text { New } \\
\text { Zealand }\end{array}$ & $\mathrm{C} 26$ & Female & $\begin{array}{l}\text { With } \\
\text { friend }\end{array}$ & $\begin{array}{l}\text { Searching for Food in } \\
\text { Xiamen in March }\end{array}$ & China \\
\hline
\end{tabular}

Note: C1-C21 for coding, and C22-C26 saturation test. 
Table 4. Themes of tourist perceived safety of destinations

\begin{tabular}{|c|c|c|c|c|c|c|c|}
\hline Dimensions & Themes & Perce & tage & Dimension & Theme & Perce & age \\
\hline \multirow{4}{*}{ PSH } & Tour guide & $1.5 \%$ & \multirow{4}{*}{$13.9 \%$} & \multirow{5}{*}{ PSSE } & Transportation & $9.2 \%$ & \multirow{5}{*}{$39.6 \%$} \\
\hline & Tourism operator & $6.7 \%$ & & & Sanitation & $5.1 \%$ & \\
\hline & Resident & $4.1 \%$ & & & Public safety & $11.8 \%$ & \\
\hline & Other tourists & $1.5 \%$ & & & Consumption safety & $10.8 \%$ & \\
\hline \multirow{4}{*}{ PSFE } & Fully equipped & $1.5 \%$ & \multirow{4}{*}{$5.6 \%$} & & Political instability & $2.5 \%$ & \\
\hline & Professional facility & $0.5 \%$ & & \multirow{7}{*}{ PSM } & Safety inspection & $1.5 \%$ & \\
\hline & Good quality & $2.5 \%$ & & & Warning system & $0.5 \%$ & \\
\hline & Convenient and comfortable & $1.0 \%$ & & & & & \\
\hline \multirow{4}{*}{ PSNE } & Weather & $9.7 \%$ & \multirow{4}{*}{$34.5 \%$} & & Safety & $2.0 \%$ & $6.1 \%$ \\
\hline & Landscape & $18.0 \%$ & & & communication & & \\
\hline & Sightseeing environment & $6.1 \%$ & & & Dolice comohility & $20^{0} \%$ & \\
\hline & Disaster & $0.5 \%$ & & & Police capability & $2.0 \%$ & \\
\hline
\end{tabular}


Table 5. Second initial item pool for TPSD generated from content analysis

\begin{tabular}{ll}
\hline \multicolumn{1}{c}{ Items } & \multicolumn{1}{c}{ Sample coded statement } \\
\hline PSH & "On the way from Yajiang to Litang, our car fell into the mud three times. \\
$\begin{array}{l}\text { Other tourists I met during the tour show } \\
\text { friendliness to me }\end{array}$ & $\begin{array}{l}\text { And people in the same car helped us twice, including push the car and } \\
\text { lending us ropes. Many thanks to them." (C18-1-1) } \\
\text { "There are full-time doctors, bellmen, pianists, masseurs and other servants } \\
\text { safety ability }\end{array}$ \\
\hline PSFE & in the car, and their service is very professional." (C5-1-2)
\end{tabular}

I didn't encounter any danger when using the facility

"There are 3 million cars in Cairo. And no matter how old the car is, it can be driven on forever because there is no motor vehicle retirement system in Egypt." (C21-2-1)

The destination facility feels comfortable to use

"Cars in India are very slow. The seats on the car are crowded and the distance between the front and rear is small. Fortunately, I was sitting in the first row, not so hard." (C2-2-2)

The destination facility is used without "The car stop-and-go along the crowded and noisy road. We also saw very failure old trams." (C21-2-3)

PSNE

The destination is less prone to natural disasters

"The flame of the lighthouse shines through the entire Alexandria port and burned for nearly a thousand years before being destroyed by the earthquake." (C21-3-1)

"Several small courtyards are very elegant. The scenery of the Jiangnan

The destination's natural environment is clean and tidy gardens is very good, and the rubbings written by celebrities are scattered throughout. Also, the environment is quiet and elegant, making people forget to return." (C1-3-2)

There are no safety hazards in the natural environment of the destination

"The yellow shoal looks dry and seems to be quite solid. But after a while, it became soft. I turned and wanted to quit, but suddenly my body quickly fell and reached the knee." (C1-3-3)

\section{PSSE}

I rarely encounter political conflicts at the destination

"Egypt's protests on January 25, 2011 caused me to worry, and the situation has been chaotic." (C21-4-1)

"Many merchants suddenly rushed up and surrounded us. A merchant put a

I rarely encounter forced consumption at the destination white Arab headscarf in my hand and said: "China, no money, no money". Then, the second merchant took my hat and forced the headscarf to wear on the head. The third merchant wanted to grab the camera and took pictures for me. Finally, the fourth began to ask for money." (C21-4-2)

I rarely encounter fraud at the destination

I rarely encounter overcrowded and messy conditions at the destination

"They must be colluding. The people who agreed with us last night hid, and others came out and scammed our money as much as possible." (C15-4-3) "The ceremony of the Ganges Sacrifice has not yet begun, but the venue has been crowded with people. We are here at 5 o'clock." (C21-4-4) "In addition to the lively night scenery and night market, it is best not to go

I rarely encounter violence at the destination, such as fighting out at night. I heard about the news of robbery or even murder at night." (C10-4-5)

PSM

I can see warning sign about security at the "The roads in New Zealand are very flat, even in the NATIONAL PARK, destination the safety signs are very clear. And won't get lost." (C13-5-1) Tourism enterprises provide tourists with "Free means that the service facilities in the scenic area may not be
complete, and it will not remind you of security issues. And security issues safety information can only be noticed by yourself." (C10-5-2)

Rigorous safety inspection are carried out at "The security check at the destination is very strict and you can see the the tourist destination soldiers with guns." (C15-5-3)

Note: C18-1-1 represents the 18th tourists' blog, which is sorted into the first item of the first dimension. 
Table 6. Results of content validity testing

\begin{tabular}{lll}
\hline \multicolumn{1}{c}{ Initial item pool } & \multicolumn{1}{c}{ Initial item pool with content validity } \\
\hline The tour leader has a professional ability (L) & PHS-01. Tour guides can take care of me safety \\
Tourism practitioners has a professional safety ability & $\begin{array}{l}\text { PHS-02. Tourism practitioners has a professional safety } \\
\text { ability }\end{array}$ \\
(G) & PHS-03. Tourism practitioners can provide service \\
PSH Put a lot of effort into job try to satisfy customers (L) & safely \\
& Local people are friendly (L) & PHS-04. Local people are friendly
\end{tabular}

The tour leader shows friendliness (L); Hospitable and friendly people (L); Other tourists I met during the tour show friendliness to me $(\mathrm{G})$

Has a good infrastructure (communication service, etc.) (L) A first aid kit in hotel room (L); A flash light in hotel room (L); A face mask for each guest for smoke, disease (L); Walk-in metal detector at the hotel (L); Continuing

PSFE airport temperature/thermal check (L)

Local transport engaged to visit tourist places (L); The destination facility feels comfortable to use $(G)$

PHS-05. The people I met during the tour show friendliness to me

PSFE-01. The destination facility is reliable in performance

PSFE-02. The destination facility looks safe and secure

Safety of the coach is reliable (L); The destination facility PSFE-04. The destination facility is used without is used without failure $(\mathrm{G})$

I didn't encounter any danger when using the facility $(\mathrm{G})$

PSFE-05. I didn't encounter any danger when using the facility

Spectacular landscape (L)

PNES-01. The quality of the natural environment of destination is favored by tourists.

The destination's natural environment is clean and tidy PNES-02. The destination's natural environment is clean (G) and tidy

PSN There are no safety hazards in the natural environment of PNES-03. There are no safety hazards in the natural

E the destination $(\mathrm{G})$

environment of the destination

The destination is less prone to natural disasters $(\mathrm{G})$

Good weather/pleasant weather (L)

PNES-04. The destination is less prone to natural disasters

PNES-05. There is no need to worry about extreme natural conditions at the destination, such as weather.

I rarely encounter overcrowded and messy conditions at PSES-01. I rarely encounter overcrowded and messy the destination $(\mathrm{G})$

Performing leisure activities such as shopping, adventure, roaming and photography is safe (L); I rarely encounter forced consumption at the destination $(\mathrm{G})$ Shopping shores have good reputation (L); A good shopping place (L); I rarely encounter fraud at the

PSSE destination $(\mathrm{G})$

I rarely encounter violence at the destination, such as fighting $(\mathrm{G})$

Walking streets after dark is safe (L); Driving around city is safe (L)

Using public transport is safe (L); Local standard of cleanliness and hygiene are high (L); I rarely encounter political conflicts at the destination $(\mathrm{G})$

I can see warning sign about security at the destination (G) conditions at the destination

PSES-02. I rarely encounter forced consumption at the destination

PSES-03. I rarely encounter fraud and theft at the destination

PSES-04. I rarely encounter violence at the destination, such as fighting

PSES-05. I rarely encounter public security problems at the destination

Item with low possibility were deleted

Good tourist information is really available (L)

The police do their job well (L); Police officers attempt

PSM to maintain a safe environment for tourists (L);

Rigorous safety inspection are carried out at the tourist destination $(\mathrm{G})$

Tsunami warning system on beaches (L); Evacuation warning system linked to guest room (L)

A crisis management plan of service providers (L); Rehearsal of evacuation plan for emergency (L);

PMS-01. I can see warning sign about security at the destination

PMS-02. I can receive the safety information provided by the destination.

PMS-03. The security work of the destination is very effective.

PMS-04. The safety construction of the destination is good.

PMS-05. Amounts of resources are invested by the destination to protect tourists' safety 
Tourism enterprises provide tourists with safety

information $(\mathrm{G})$

Note: L represents the item generate from literature, and $\mathrm{G}$ represents the item generate from content analysis.

Table 7. Respondent profile

\begin{tabular}{|c|c|c|c|c|c|}
\hline \multirow{2}{*}{ Variable } & \multirow{2}{*}{ Category } & \multicolumn{2}{|c|}{ Study $2(n=300)$} & \multicolumn{2}{|c|}{ Study $3(n=1,830)$} \\
\hline & & Frequency & Rate & Frequency & Rate \\
\hline \multirow{2}{*}{ Gender } & Male & 146 & $48.7 \%$ & 836 & $45.68 \%$ \\
\hline & Female & 154 & $51.3 \%$ & 994 & $54.32 \%$ \\
\hline \multirow{6}{*}{ Age } & $\leq 17$ & 13 & $4.3 \%$ & 102 & $5.57 \%$ \\
\hline & $18-24$ & 170 & $56.7 \%$ & 692 & $37.81 \%$ \\
\hline & $25-34$ & 78 & $26.0 \%$ & 520 & $28.42 \%$ \\
\hline & $35-44$ & 26 & $8.7 \%$ & 315 & $17.21 \%$ \\
\hline & $45-64$ & 10 & $3.3 \%$ & 159 & $8.69 \%$ \\
\hline & $\geq 65$ & 3 & $1.0 \%$ & 42 & $2.30 \%$ \\
\hline \multirow{4}{*}{ Education } & $\begin{array}{l}\text { Senior middle school and } \\
\text { below }\end{array}$ & 60 & $20.0 \%$ & 441 & $24.10 \%$ \\
\hline & Technical secondary school & 55 & $18.3 \%$ & 452 & $24.70 \%$ \\
\hline & Undergraduate & 164 & $54.7 \%$ & 820 & $44.81 \%$ \\
\hline & Graduate and above & 21 & $7.0 \%$ & 117 & $6.39 \%$ \\
\hline \multirow{10}{*}{ Occupation } & Staff & 56 & $18.7 \%$ & 289 & $15.79 \%$ \\
\hline & Government official & 18 & $6.0 \%$ & 106 & $5.79 \%$ \\
\hline & Researcher & 9 & $3.0 \%$ & 137 & $7.49 \%$ \\
\hline & Self-employed & 15 & $5.0 \%$ & 161 & $8.80 \%$ \\
\hline & Soldier & 6 & $2.0 \%$ & 16 & $0.87 \%$ \\
\hline & Student & 140 & $46.7 \%$ & 617 & $33.72 \%$ \\
\hline & Professionals and technical & 9 & $3.0 \%$ & 92 & $5.03 \%$ \\
\hline & Freelance & 16 & $5.3 \%$ & 174 & $9.51 \%$ \\
\hline & Retired & 4 & $1.3 \%$ & 86 & $4.70 \%$ \\
\hline & Other & 27 & $9.0 \%$ & 152 & $8.31 \%$ \\
\hline \multirow{5}{*}{ Monthly income } & Below 1999 RMB & 160 & $53.5 \%$ & 700 & $38.25 \%$ \\
\hline & 2000-4999 RMB & 96 & $32.0 \%$ & 692 & $37.81 \%$ \\
\hline & 5000-7999 RMB & 28 & $9.3 \%$ & 275 & $15.03 \%$ \\
\hline & 8000-9999 RMB & 8 & $2.7 \%$ & 81 & $4.43 \%$ \\
\hline & Above $10000 \mathrm{RMB}$ & 8 & $2.7 \%$ & 82 & $4.48 \%$ \\
\hline \multirow{5}{*}{ Travel frequency } & Hardly & 20 & $53.3 \%$ & 152 & $8.31 \%$ \\
\hline & Seldom & 92 & $32.0 \%$ & 598 & $32.68 \%$ \\
\hline & Sometime & 112 & $9.3 \%$ & 657 & $35.90 \%$ \\
\hline & Often & 68 & $2.3 \%$ & 375 & $20.49 \%$ \\
\hline & Usually & 8 & $3.1 \%$ & 48 & $2.62 \%$ \\
\hline
\end{tabular}


Table 8. Results of EFA

\begin{tabular}{|c|c|c|c|c|}
\hline \multirow{2}{*}{ Dimension and Item Description } & \multicolumn{4}{|c|}{ Study $2(\mathrm{n}=300)$} \\
\hline & Mean & SD & Factor loadings & Variance \\
\hline \multicolumn{5}{|l|}{ Factor 1: PSH (5 items, Cronbach' $\alpha=0.862$ ) } \\
\hline PSH-01 & 3.40 & 0.87 & 0.688 & \multirow{5}{*}{$14.054 \%$} \\
\hline PSH-02 & 3.51 & 0.88 & 0.806 & \\
\hline PSH-03 & 3.63 & 0.81 & 0.704 & \\
\hline PSH-04 & 3.75 & 0.85 & 0.654 & \\
\hline PSH-05 & 3.71 & 0.84 & 0.655 & \\
\hline \multicolumn{5}{|l|}{ Factor 2: PSFE ( 5 items, Cronbach' $\alpha=0.882$ ) } \\
\hline PSFE-01 & 3.55 & 0.84 & 0.710 & \multirow{5}{*}{$14.556 \%$} \\
\hline PSFE-02 & 3.63 & 0.81 & 0.680 & \\
\hline PSFE-03 & 3.61 & 0.83 & 0.707 & \\
\hline PSFE-04 & 3.79 & 0.88 & 0.668 & \\
\hline PSFE-05 & 3.91 & 0.86 & 0.630 & \\
\hline \multicolumn{5}{|c|}{ Factor 3: PSNE (3 items, Cronbach' $\alpha=0.865$ ) } \\
\hline PSNE-03 & 3.43 & 0.94 & 0.697 & \multirow{3}{*}{$11.242 \%$} \\
\hline PSNE-04 & 3.38 & 0.96 & 0.805 & \\
\hline PSNE-05 & 3.37 & 1.04 & 0.846 & \\
\hline \multicolumn{5}{|l|}{ Factor 4: PSSE ( 5 items, Cronbach' $\alpha=0.871$ ) } \\
\hline PSSE-01 & 3.03 & 1.04 & 0.704 & \multirow{5}{*}{$14.894 \%$} \\
\hline PSSE-02 & 3.40 & 1.05 & 0.780 & \\
\hline PSSE-03 & 3.14 & 1.13 & 0.767 & \\
\hline PSSE-04 & 3.63 & 0.90 & 0.692 & \\
\hline PSSE-05 & 3.66 & 0.92 & 0.673 & \\
\hline \multicolumn{5}{|l|}{ Factor 5: PSM (5 items, Cronbach' $\alpha=0.852$ ) } \\
\hline PSM-01 & 3.88 & 0.89 & 0.739 & \multirow{5}{*}{$13.789 \%$} \\
\hline PSM-02 & 3.77 & 0.82 & 0.778 & \\
\hline PSM-03 & 3.56 & 0.78 & 0.713 & \\
\hline PSM-04 & 3.50 & 0.81 & 0.576 & \\
\hline PSM-05 & 3.59 & 0.80 & 0.640 & \\
\hline
\end{tabular}


Table 9. Results of CFA

\begin{tabular}{|c|c|c|c|c|c|}
\hline \multirow[b]{2}{*}{ Dimensions } & \multicolumn{5}{|c|}{ Study $3(\mathrm{n} 1=915)$} \\
\hline & Mean & SD & $\begin{array}{c}\text { Standardized } \\
\text { Factor Loadings }\end{array}$ & $\mathrm{CR}$ & AVE \\
\hline \multicolumn{6}{|c|}{ PSH (4 items, Cronbach' $\alpha=0.811$ ) } \\
\hline PSH_01 & 3.59 & 0.93 & 0.733 & \multirow{4}{*}{0.8196} & \multirow{4}{*}{0.5347} \\
\hline PSH_02 & 3.74 & 0.85 & 0.807 & & \\
\hline PSH_03 & 3.79 & 0.82 & 0.769 & & \\
\hline PSH_04 & 3.92 & 0.86 & 0.599 & & \\
\hline \multicolumn{6}{|c|}{ PSFE (4 items, Cronbach' $\alpha=0.816$ ) } \\
\hline PSFE_01 & 3.72 & 0.88 & 0.796 & \multirow{4}{*}{0.8203} & \multirow{4}{*}{0.5350} \\
\hline PSFE_02 & 3.76 & 0.82 & 0.776 & & \\
\hline PSFE_03 & 3.85 & 0.83 & 0.715 & & \\
\hline PSFE_05 & 3.95 & 0.86 & 0.627 & & \\
\hline \multicolumn{6}{|c|}{ PSNE ( 3 items, Cronbach' $\alpha=0.758$ ) } \\
\hline PSNE_03 & 3.67 & 0.88 & 0.695 & \multirow{3}{*}{0.7599} & \multirow{3}{*}{0.5136} \\
\hline PSNE_04 & 3.64 & 0.93 & 0.745 & & \\
\hline PSNE_05 & 3.65 & 0.96 & 0.709 & & \\
\hline \multicolumn{6}{|c|}{ PSSE ( 5 items, Cronbach' $\alpha=0.836$ ) } \\
\hline PSSE_01 & 3.22 & 1.10 & 0.609 & \multirow{5}{*}{0.8407} & \multirow{5}{*}{0.5152} \\
\hline PSSE_02 & 3.53 & 1.01 & 0.717 & & \\
\hline PSSE_03 & 3.48 & 1.02 & 0.727 & & \\
\hline PSSE_04 & 3.75 & 0.92 & 0.787 & & \\
\hline PSSE_05 & 3.83 & 0.90 & 0.737 & & \\
\hline \multicolumn{6}{|c|}{$\operatorname{PSM}(4$ items, Cronbach' $\alpha=0.808)$} \\
\hline PSM_02 & 3.80 & 0.85 & 0.644 & \multirow{4}{*}{0.8101} & \multirow{4}{*}{0.5170} \\
\hline PSM_03 & 3.74 & 0.82 & 0.742 & & \\
\hline PSM_04 & 3.69 & 0.84 & 0.742 & & \\
\hline PSM_05 & 3.77 & 0.82 & 0.743 & & \\
\hline
\end{tabular}

Table 10. Correlations and square roots of AVE $(\mathrm{n} 1=915)$

\begin{tabular}{lccccc}
\hline Dimensions & Factor 1 & Factor 2 & Factor 3 & Factor 4 & Factor 5 \\
\hline Factor 1: PSH & $(0.731)$ & & & & \\
Factor 2: PSFE & $0.573^{* *}$ & $(0.731)$ & & & \\
Factor 3: PSNE & $0.394^{* *}$ & $0.441^{* *}$ & $(0.717)$ & $(0.718)$ & $(0.719)$ \\
Factor 4: PSSE & $0.471^{* *}$ & $0.542^{* *}$ & $0.435^{* *}$ & $0.538^{* *}$ & \\
Factor 5: PSM & $0.577^{* *}$ & $0.524^{* *}$ & $0.510^{* *}$ & 0.40 \\
\hline
\end{tabular}

Note: 1 . The diagonal element is the square root of the extracted mean variance; 2 . The off-diagonal element are correlations between dimensions $(p<0.01)$.

Table 11. Model comparison of TPSD (n2=915)

\begin{tabular}{|c|c|c|c|c|}
\hline Goodness-fit-indices & Model 1 & Model 2 & Model 3 & Model 4 \\
\hline RMSEA & 0.130 & 0.107 & 0.054 & 0.055 \\
\hline RMR & 0.115 & 0.213 & 0.034 & 0.038 \\
\hline CFI & 0.654 & 0.766 & 0.945 & 0.940 \\
\hline NFI & 0.641 & 0.750 & 0.926 & 0.920 \\
\hline TLI & 0.616 & 0.739 & 0.935 & 0.931 \\
\hline IFI & 0.655 & 0.767 & 0.945 & 0.940 \\
\hline GFI & 0.740 & 0.777 & 0.938 & 0.933 \\
\hline AGFI & 0.681 & 0.724 & 0.918 & 0.915 \\
\hline
\end{tabular}




\begin{tabular}{ccccc}
\hline PGFI & 0.603 & 0.629 & 0.714 & 0.733 \\
$\chi^{2}$ & 2822.250 & 1961.102 & 582.712 & 627.375 \\
$d f$ & 171 & 170 & 160 & 165 \\
$\chi^{2} d f$ & 16.504 & 11.536 & 3.642 & 3.802 \\
\hline
\end{tabular}

Table 12. Results of cross validity test $(n 2=915)$

\begin{tabular}{lcc}
\hline \multicolumn{3}{c}{ Measurement models } \\
\hline Goodness-fit-indices & Random split (457 or 458) \\
RMSEA & Unconstrained & Measurement weights \\
RMR & 0.040 & 0.039 \\
CFI & 0.037 & 0.040 \\
NFI & 0.940 & 0.940 \\
TLI & 0.903 & 0.901 \\
IFI & 0.928 & 0.931 \\
GFI & 0.940 & 0.940 \\
AGFI & 0.920 & 0.918 \\
$\chi^{2}$ & 0.895 & 0.898 \\
$d f$ & 785.024 & 801.336 \\
$\chi^{2} / d f$ & 320 & 335 \\
\hline
\end{tabular}


Table 13. Results of criterion-related validity $(\mathrm{n} 1=915)$

\begin{tabular}{lcc}
\hline & TPSS & PS \\
& (Cronbach's alpha $=0.826)$ & (Cronbach's alpha $=0.811)$ \\
\hline PSH & $0.492^{* *}$ & $0.401^{* *}$ \\
PSFE & $0.488^{* *}$ & $0.290^{* *}$ \\
PSNE & $0.426^{* *}$ & $0.324^{* *}$ \\
PSSE & $0.387^{* *}$ & $0.379^{* *}$ \\
PSM & $0.394^{* *}$ & $0.391^{* *}$ \\
TPSD & $0.566^{* *}$ & $0.470^{* *}$ \\
\hline
\end{tabular}

Note: ${ }^{* *} p<0.01$ 


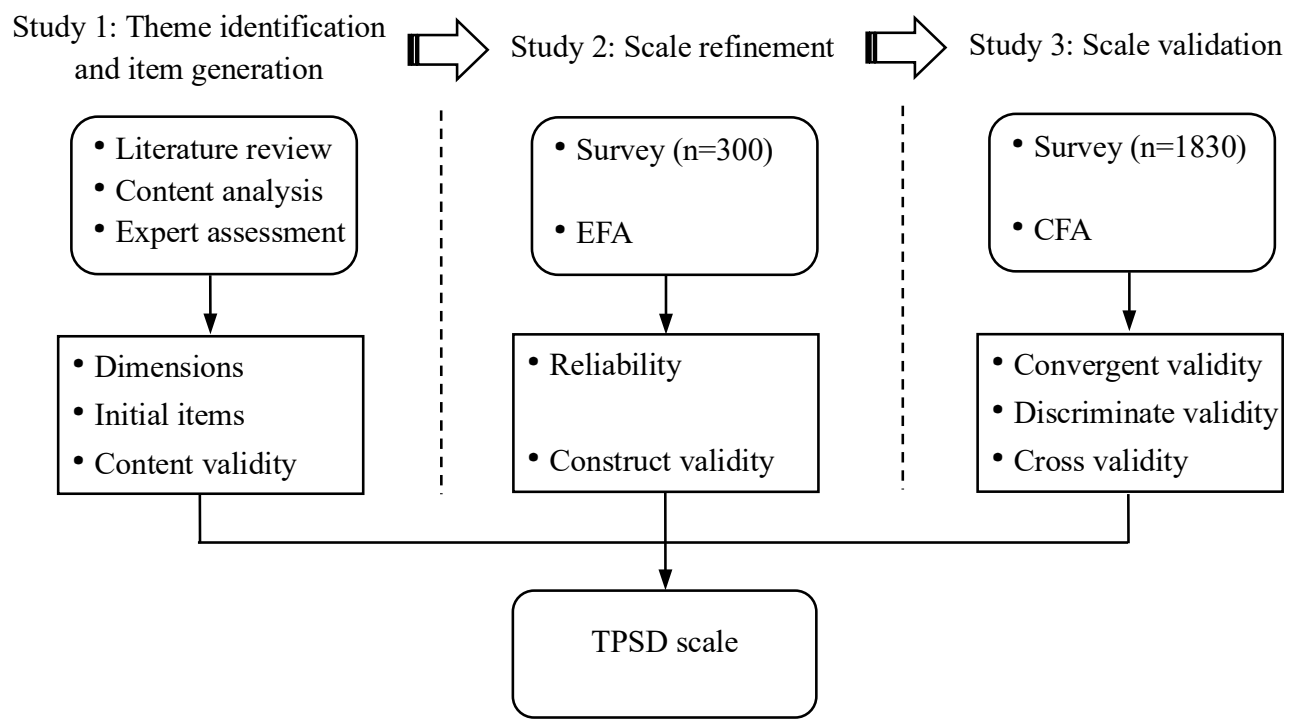

Fig.1. Methodological procedure of scale development 


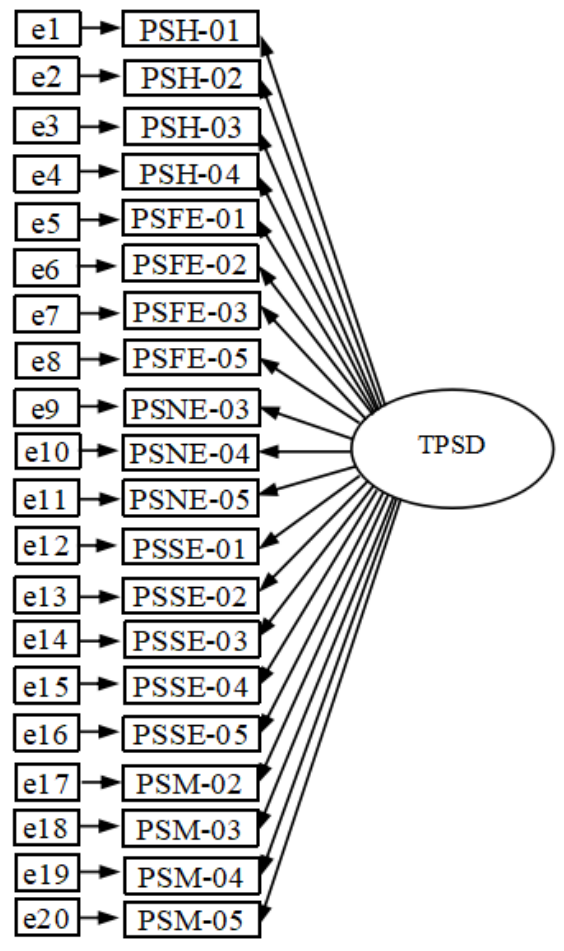

Figure 2-1

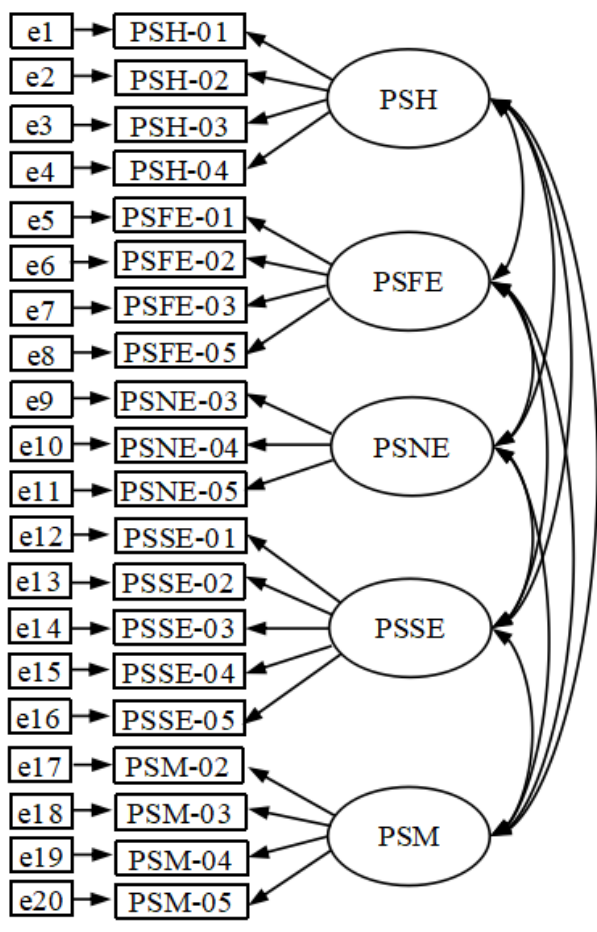

Figure 2-3

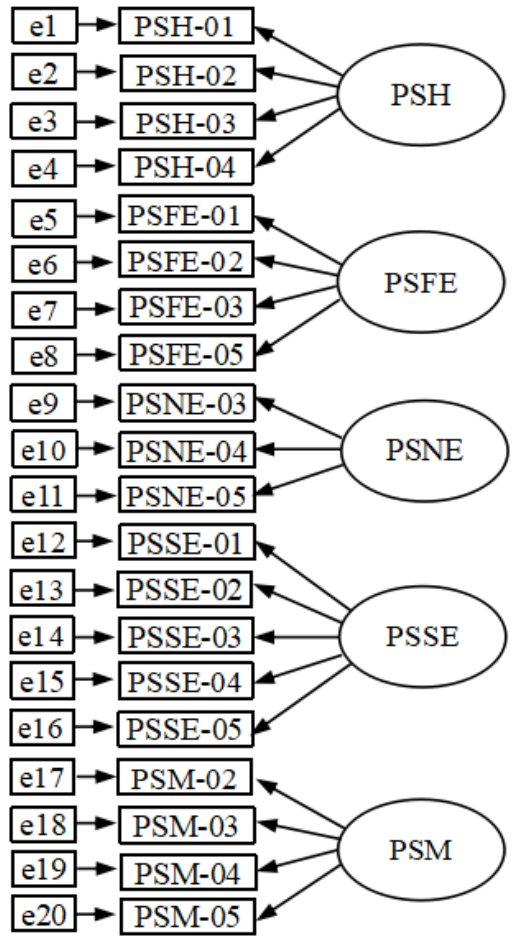

Figure 2-2

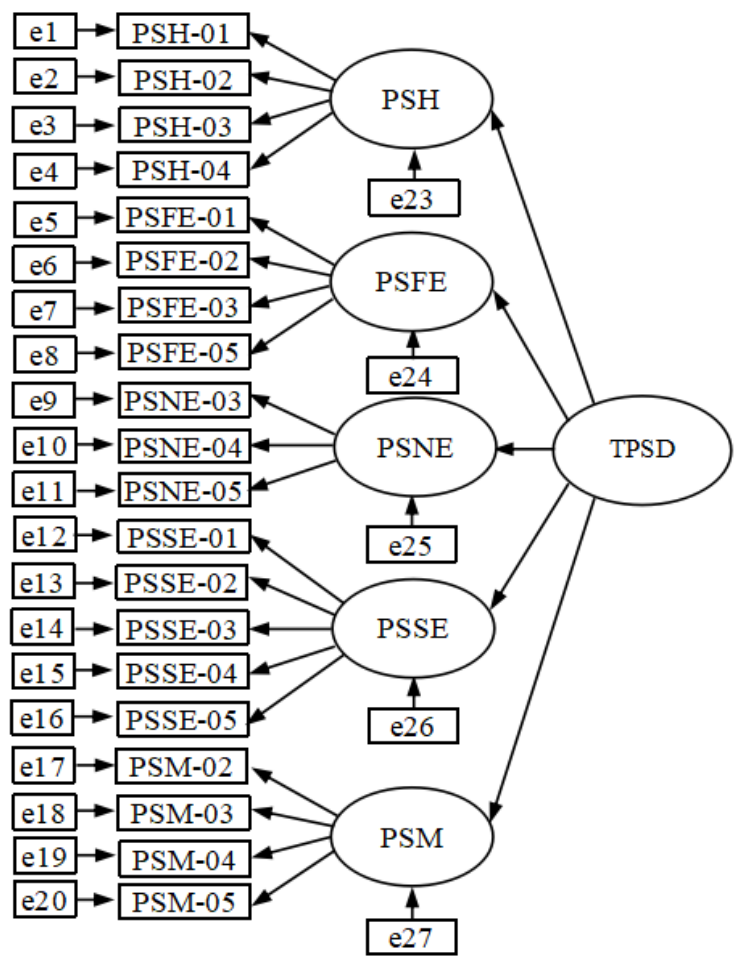

Figure 2-4

Fig. 2. Model comparison of TPSD 